\title{
Rental Service Market of Farm Machinery in Rice Cultivation: A Farm Level Investigation
}

\author{
A K M S Islam* and M J Kabir
}

\begin{abstract}
This study was undertaken to investigate the rental charge and labour cost of five major operations in rice production in the north-west region of Bangladesh. Farmers' group discussions (FGDs) with 10-15 key informants farmers were conducted for collecting farm level data from 15 villages of both Rajshahi and Rangpur divisions. Rental charge and labour cost of rice cultivation were converted to paddy equivalent cost (PEC) for tillage, transplanting, weeding, harvesting, carrying and threshing. Farmers mostly relied on the service providers of either power tiller or tractor for tillage. They also relied on the service providers of close drum power thresher for threshing rice and other crops. However, farmers still manually carried out transplanting, weeding, harvesting and carrying of rice. Both the contractual and daily basis hired labour and family labour performed those activities. The wages of labour of harvesting and carrying was paid in cash or kind (e.g., share of harvested grain or fixed amount of grain per unit of harvest area). The average paddy equivalent cost for the five major operations was ranged between $37-47 \%$ of total paddy production cost in the study locations. The mechanized transplanting and harvesting may reduce rice production cost largely as well as would resolve the labour scarcity problems. Therefore, transplanter and harvester have the great prospect of widespread adoption. However, prospect of mechanical weeding is limited because of the availability of low cost intensive chemical control methods. Thus, providing the larger financial assistance on purchasing both the transplanter and harvester facilitates the end users to enhance the productivity and reduce the cost of rice farming.
\end{abstract}

Key words: Entrepreneurship, labour, rental charge, paddy equivalent charge, profit

\section{INTRODUCTION}

Rice is the main staple food and grown in the three distinct seasons- namely Boro (DecApril), Aus (April-July), and Aman (Aug-Nov) in Bangladesh. The crop is cultivated over $80 \%$ of the total cropped areas in the country (Kabir et al., 2016a). Farmers in some areas of the country compelled to delay transplanting and harvesting rice due to sacrcity of labour at peak period (Sattar, 1999). The scarcity of labour for farming has been increasing due to shifted offfarm wage workers to the non-farm wage work as well as farming is not a preferred livelihood options to younger generation (Kabir et al. 2017a; Kabir et al. 2017b). Therefore, agricultural mechanization is critically important for sustainable rice production. In this respect, rental system or custom hire service of the farm machinery could be an option to promote farm mechanization in the country (Islam, 2016). In addition, it may create self-employment opportunities for the rural people.

The private entrepreneurs are the main actors of the rental service of farm machinery for land preparation, planting, weeding, and harvesting. They provide services of farm machinery to the farmers on neighbour to neighbour basis.

However, an insufficient support service, poverty and lack of awareness identified as the main constraints of promoting entrepreneurship in Kenya (FAO, 2006). Despite, on average about $51 \%$ farmers relied on own machinery and rest dependent on service providers on custom hire basis for tillage and harvesting crops in the southern and central Iraq (Bishay, 2003). Local large-scale landowner provided the rental service with heavy spike-toothed thresher (50\% locally manufactured) in Nepal

Bangladesh Rice Research Institute, Gazipur. *Corresponding authors’ E-mail: akmsaifulislam68@gmail.com 
(Justice and Biggs, 2010). On the contrary, small-scale enterprises provided the harvesting and threshing services for rice and wheat with the hired combine harvesters to the small and medium size landholders (typically with two acres) in the Gujranwala district of Punjab province in Pakistan. The rental charge varied according to crop density, weed populations, expected yields, ground conditions, and transport distance (Sims et al., 2011).

The farm mechanization in Bangladesh commenced through introduction of irrigation pump for boro rice cultivation with the direction of government in 1970. Thereafter, private entrepreneurship has developed on farm mechanization such as power tractor, pump and thresher. The two wheel and four wheel tractors are locally known as power tiller and tractor respectively in the country. Besides tillage, the power tiller and tractor are widely used for carrying goods with trolley and threshing rice in the off peak tillage season. Most of the farmers including small, medium and some large are relied on the service providers for tillage. Table 1 presents statistics of farm machinery used in rice cultivation in Bangladesh. Few transplanter, weeder, fertilizer applicator, reaper and harvester were used in the country. Mechanized transplanting is being started recently using 4-row walking type transplanter through public and private sector intervention (Islam, 2016). Reaper and harvester is gaining attention to the farmers. Research institutes, department of agricultural extension, private sector and non-government organization are actively involved to promote transplanter, reaper (self propelled or power tiller mounted) and combine harvester in the country.

Transplanting, weeding, harvesting and threshing are the five labour intensive operations in rice cultivation (Islam et al. 2016a, Islam et al. 2017, Alam et al. 2014 and Islam, 2006). Farmers realized the importance of mechanical means of tillage and threshing as to take the enormous benefit of rental system. However, other labour intensive operations such as transplanting, weeding, and harvesting were accomplished manually. The farmers of Bangladesh who are very resource poor often could not afford of buying the machinerybeing deprived of the huge benefit of farm power use. There is a need to investigate the existing rental system and labour cost of five labour intensive operations in rice cultivation. Therefore, the present study was undertaken to collect information on the rental system and labour cost of five labour intensive operations to explore the service market of farm machinery in rice production.

Table 1. Present status of farm machinery in Bangladesh.

\begin{tabular}{lll}
\hline Machine & Quantity (no.) & Source \\
\hline Power tiller & $7,00,000$ & Ahmed, 2014 \\
Tractor & 60,000 & Ahmed, 2014; Kabir, 2014 \\
Rice transplanter & 300 & Islam, 2016 \\
Weeder & $2,50,000$ & Ahmed, 2014 \\
Granular urea applicator & 800 & Ahmed, 2014 \\
Prilled urea applicator & 18,000 & MoA, 2016 \\
Sprayer & $13,00,000$ & Ahmed, 2014 \\
Reaper & 500 & Ahmed, 2014 \\
Combine harvester & 130 & Ahmed, 2014; Kabir, 2014 \\
Open drum thresher & $1,50,000$ & MoA, 2016 \\
Closed drum thresher & $2,20,000$ & MoA, 2016 \\
\hline
\end{tabular}




\section{METHODOLOGY}

Amultistage sampling wasappliedforthisstudy. At first, 15 districts were selected randomly from the north-west regions of Bangladesh. Thereafter, one upazila was selected randomly from each of the selected districts and a village was selected from each of the selected 15 upazilas. Finally, 10-15 key informant farmers was selected purposively for farmers group discussion (FGD) to delineate with the existing situation of farm machinery rental service. One FGD was conducted in each village to collect data on rental charge of farm machinery, labour cost of major intercultural operations of rice cultivation and farmers opinions about using farm machinery and availability of labour for farming during January-March 2017 (Table 2). The data were summarized in crop production stage wise and discussed in administrative division wise. Labour cost and rental charge of farm machinery in five major operations of rice cultivation were converted to paddy equivalent cost to estimate the percent of total rice production went away for those operations as the rural economy was regulated by the paddy price. The procurement price of boro paddy (Tk
2,400 per ton) was used for estimating paddy equivalent cost of production (DOF, 2017). The average yield of cleaned rice was considered as 3.17 ton per hectare (Kabir et al., 2016b) and used to calculate the rental charge and labour cost of each farming activity in the percentage of paddy production.

\section{RESULTS AND DISCUSSION}

\section{Tillage}

Farmers in the group discussion said that they used power tractor on rental basis in tillage operation in the case study villages of Rajshahi division. They also mentioned that the service provider only tilled the crop fields; thereafter; the lands owners levelled the land manually for transplanting rice. Table 3 shows that farmers in the survey villages in Chapainawabganj, Naogaon, Natore and Rajshahi districts relied on power tiller for land preparation while farmers in the rest of the locations used both the power tiller and tractor. It was found that irrespective of tractor type, two passes were needed for good pulverization of soil in most of the survey locations except in the Bogra and Rajshahi

Table 2. Study locations.

\begin{tabular}{llll}
\hline Division & District & Upazila & Village \\
\hline Rangpur & Bogra & Sadar & Kanar \\
& Dinajpur & Sadar & Paschim Khudihar para \\
Gaibandha & Gobindaganj & Digholkandi \\
Kurigram & Mogolbasha & Uttar Naowabas \\
Lalmonirhat & Sadar & Haridev \\
Panchagarh & Sadar & 10 no. Gorinabari \\
Rangpur & Sadar & Ghaghotpara \\
& Thakurgaon & Sadar & Kismat Daulatpur \\
& Chapainawabganj & Shibganj & Shekhtola \\
Rajshahi & Joypurhat & Sadar & Hismi Bazar \\
& Naogaon & Sadar & Toruk \\
& Natore & Sadar & Khandarpar \\
& Pabna & Bera & Fokirkandi \\
& Rajshahi & Paba & Mohonpur \\
& Sirajganj & Ullapara & Choria chockpara \\
\hline
\end{tabular}


Table 3. Rental charge of power tiller and tractor in tilling the land for transplanting rice in Rajshahi division.

\begin{tabular}{|c|c|c|c|c|c|c|}
\hline \multirow{2}{*}{ District } & \multicolumn{3}{|c|}{ Power tiller } & \multicolumn{3}{|c|}{ Tractor } \\
\hline & $\begin{array}{l}\text { Pass } \\
\text { no. }\end{array}$ & 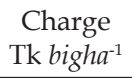 & $\begin{array}{l}\text { Paddy equivalent } \\
\text { charge kg } \text { bigh }^{-1}\end{array}$ & $\begin{array}{l}\text { Pass } \\
\text { no. }\end{array}$ & 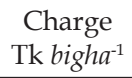 & $\begin{array}{l}\text { Paddy equivalent } \\
\text { charge } \mathrm{kg} b i g h a^{-1}\end{array}$ \\
\hline Bogra & 4 & 900 & $38(6)$ & 3 & 1,000 & $42(6)$ \\
\hline Chapainawabganj & 2 & 700 & $29(4)$ & - & - & - \\
\hline Joypurhat & 2 & 1,000 & $42(6)$ & 2 & 1,200 & $50(8)$ \\
\hline Naogaon & 2 & 700 & $29(4)$ & - & - & - \\
\hline Natore & 2 & 800 & $33(5)$ & - & - & - \\
\hline Pabna & 2 & 1,000 & $42(6)$ & 2 & 1,000 & $42(6)$ \\
\hline Rajshahi & 4 & 1,200 & $50(8)$ & - & - & - \\
\hline Sirajganj & 2 & 1,100 & $46(7)$ & 2 & 1,200 & $54(8)$ \\
\hline Average & 3 & 938 & $39(6)$ & 2 & 1,100 & $46(7)$ \\
\hline
\end{tabular}

Source: Field survey 2017. Note: Figures in the bracket is the paddy equivalent charge of tillage as percent of total paddy production in per bigha land. One bigha equals 33 decimal.

districts. Similarly, it is reported that farmers relied on service providers for tillage in the southern coastal areas in Bangladesh (Kabir et al. 2007b). Not surprisingly, per bigha rental charge of tractor (Tk 1,000-1,300) was higher than that for power tiller (Tk 700-1,200). It was also the case that per bigha paddy equivalent rental charges of power tiller and tractor were $37-50 \mathrm{~kg}$ and $41-54 \mathrm{~kg}$, respectively. It can be noted that the paddy equivalent rental charge of tillage either by power tiller or tractor was ranged between $6-7 \%$ of total rice production in the per unit area. The key drivers of adoption of four wheel tractors were (i) deep tillage (ii) better pulverization and (iii) faster in tillage operation.

Similarly, in the survey villages in Rangpur division, most of the farmers hired power tiller on rental basis for tilling the lands like that of Rajshahi regions. The key informants mentioned that draft power was used for tillage only in a few plots having difficulties to access power tiller. Farmers said that service providers from other districts came along with their four wheels tractor in Rangpur districts as the demand was very high due to produce fine tilth of soil for sowing potatoes. Table 4 shows that the farmers in the survey villages in Thakurgaon district fully relied on tractor for tilling lands because of the larger size of the plots. On the contrary, farmers in the survey villages in Dinajpur and Panchagarh districts only used power tiller for tillage operation due to smaller size of plots. Similarly, the rental charge of tractor (TK 9001100 bigh $^{-1}$ ) in the most areas was higher than that for power tiller (Tk 800-1200 bigha ${ }^{-1}$ ) in the Rangpur division like Rajshahi division, while the number of tillage passes in Rangpur division (3-4 passes) was higher than that of Rajshahi division (2 passes). Similarly, the service providers only tilled the lands in most of the survey villages in Rangpur division like Rajshahi Division, while they tilled and levelled the land for transplanting rice in the Rangpur, Gaibandha and Panchgarh districts. Farmers in Kurigram district expressed that multiple passes were required in tillage operation due to excess weed infestation ultimately increased the cost of tillage. Farmers spent $6-7 \%$ of total rice production in the per unit area as paddy equivalent rental charge of tillage.

\section{Transplanting}

Farmers transplanted rice manually using family and hired labour in the Rajshahi division. In the group discussion, they mentioned 
Table 4. Rental charge of power tiller and tractor in tilling the land for transplanting rice in Rangpur division.

\begin{tabular}{|c|c|c|c|c|c|c|}
\hline \multirow[b]{2}{*}{ District } & \multicolumn{3}{|c|}{ Power tiller } & \multicolumn{3}{|c|}{ Tractor } \\
\hline & No. of pass & $\begin{array}{l}\text { Charge } \\
{\text { Tk } b i g h a^{-1}}^{2}\end{array}$ & 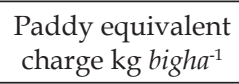 & No. of pass & $\begin{array}{l}\text { Charge } \\
{\text { Tk } b i g h a^{-1}}^{2}\end{array}$ & $\begin{array}{l}\text { Paddy equivalent } \\
\text { charge kg bigh } a^{-1}\end{array}$ \\
\hline *Rangpur & 3 & 800 & $33(4)$ & 3 & 1,000 & $42(6)$ \\
\hline${ }^{*}$ Gaibandha & 4 & 1,050 & $44(7)$ & 3 & 1,100 & $46(7)$ \\
\hline Thakurgaon & & - & - & 3 & 900 & $38(6)$ \\
\hline Dinajpur & 4 & 850 & $35(5)$ & - & - & - \\
\hline Lalmonirhut & 3 & 1,000 & $42(6)$ & 3 & 1,000 & $41(6)$ \\
\hline Kurigram & 4 & 1,200 & $50(8)$ & 4 & 1,000 & $41(6)$ \\
\hline *Panchagarh & 4 & 1,100 & $46(7)$ & - & - & - \\
\hline Average & 4 & 1,000 & $42(6)$ & 3 & 1,000 & $42(6)$ \\
\hline
\end{tabular}

Source: Field survey 2017, Note: *indicates levelling is complementary with tillage. Figures in the bracket are the paddy equivalent charge of tillage as percent of total paddy production in per bigha land. One bigha equals 33 decimal.

that the availability of labour in intercultural operations of rice had been decerased in the survey villages. It was due to migration of labourer to urban and cities for non-farm work and educated younger generation preferred non-farm occupations than farming and/or off-farm wage work. Therefore, farmers in the survey villages of Rajshahi, Chapainawabganj, Pabna and Sirajganj districts employed temporarily migrated labourer from other districts for transplanting rice in Boro season. Similarly, farmers in the Natore and Joypurhat districts relied on the migrated labour for transplanting rice in Aman season. In Nagaon district, farmers fully depended on the migrated labourer to transplant rice in both the seasons. Table 5 shows that wage rate and cost of transplanting rice varied among the districts due to availability of wage workers. Labour wages per man-days were varied and ranged between Tk 250-400. It was also the case that the farmers spent paddy equivalent labour wages of transplanting rice ranged between $8-10 \%$ of total rice production in per unit area.

Farmers in the group discussion said that both the male and female labourers took part in intercultural operations of agriculture in the survey villages in Rangpur division (Table 6). Key informants noted that there was no scarcity of labourer for intercultural operations of rice as (i) wage work is the main occupation of both the male and female members of landless tribal households and (ii) rate of seasonal labour migration from the areas to cities and other districts was low. The respondents said that per man-day wage of male worker (Tk 300-400) was higher than female worker (Tk 200-250). Rice was transplanted as line or/and traditional haphazard methods in the areas by both contractual and daily wage basis. Table 6 shows that cost of transplanting per bigha rice was higher for labourer employed as daily basis (Tk 1,200-1,280) than that for contractual basis (Tk 900-1,000). It can be noted that paddy equivalent cost of labour for transplanting rice in per bigha land was ranged between $38-50 \mathrm{~kg}$, which was about $6-8 \%$ of total rice production in per bigha land.

\section{Weeding}

Farmers mainly relied on the human labour for weeding rice fields in the survey villages of Rajshahi division. Table 7 shows that per bigha cost of labour for weeding Boro rice among the districts varied largely ie Tk 1,500-2,100 per bigha because of the variation in the number of weeding depending on the severity of weed infestation. The paddy equivalent labour cost of weeding per bigha land was ranged between 63$88 \mathrm{~kg}$, which was about $10-13 \%$ of total paddy 
Table 5. Labour cost of manual rice transplanting in Rajshahi division.

\begin{tabular}{lcccc}
\hline District & $\begin{array}{c}\text { Labour requirement } \\
\text { man-day bigha }{ }^{-1}\end{array}$ & $\begin{array}{c}\text { Wages } \\
\text { Tk man-day }{ }^{-1}\end{array}$ & $\begin{array}{c}\text { Labour cost } \\
\text { Tk bigha }{ }^{-1}\end{array}$ & $\begin{array}{c}\text { Paddy equivalent labour } \\
\text { cost kg bigha }\end{array}$ \\
\hline Bogra & 4 & 300 & 1,200 & $50(8)$ \\
Chapainawabganj & 5 & 250 & 1,250 & $52(8)$ \\
Joypurhat & 4 & 400 & 1,600 & $67(10)$ \\
Naogaon & 4 & 400 & 1,600 & $67(10)$ \\
Natore & 5 & 300 & 1,500 & $63(10)$ \\
Pabna & 4 & 300 & 1,200 & $50(8)$ \\
Rajshahi & 4 & 400 & 1,600 & $67(10)$ \\
Sirajganj & 4 & 400 & 1,600 & $67(10)$ \\
Average & 4 & 344 & 1,444 & $60(9)$ \\
\hline
\end{tabular}

Source: Field survey 2017, Note: Figures in the bracket are the paddy equivalent labour cost of transplanting as percent of total paddy production in per bigha land. One bigha equals 33 decimal.

Table 6. Labour cost of manual rice transplanting in Rangpur division.

\begin{tabular}{|c|c|c|c|c|}
\hline District & $\begin{array}{c}\text { Labour requirement } \\
\text { man-day } \text { bigha }^{-1}\end{array}$ & $\begin{array}{c}\text { Wages } \\
\text { Tk man-day }^{-1}\end{array}$ & $\begin{array}{l}\text { Labour cost } \\
\text { Tk bigha }{ }^{-1}\end{array}$ & $\begin{array}{l}\text { Paddy equivalent cost of } \\
\text { labour } \mathrm{kg} \text { bigha }^{-1}\end{array}$ \\
\hline Dinajpur & 4 & 320 & 1,280 & $53(8)$ \\
\hline Gaibandha & - & Contract & 900 & $38(6)$ \\
\hline Kurigram & 4 & 300 & 1,200 & $50(8)$ \\
\hline Panchgarh & 4 & 300 & 1,200 & $50(8)$ \\
\hline Rangpur & - & Contract & 900 & $38(6)$ \\
\hline Thakurgaon & - & Contract & 1,000 & $42(6)$ \\
\hline Average & 4 & - & 1,097 & $46(7)$ \\
\hline
\end{tabular}

Source: Field survey 2017, Note: Figures in the bracket is the paddy equivalent labour cost of transplanting as percent of total paddy production in per bigha land. One bigha equals 33 decimal.

Table 7. Labour cost of manual weeding of Boro rice in Rajshahi division.

\begin{tabular}{|c|c|c|c|c|}
\hline \multirow{2}{*}{ District } & \multicolumn{3}{|c|}{ Labour cost (Tk bigha $\left.{ }^{-1}\right)$} & \multirow{2}{*}{$\begin{array}{c}\text { Paddy equivalent } \\
\text { labour cost }\left(\mathrm{kg} b i g h a^{-1}\right)\end{array}$} \\
\hline & First weeding & Second weeding & Total & \\
\hline Bogra & 1,000 & 500 & 1,500 & $63(10)$ \\
\hline Chapainawabganj & 1,100 & 600 & 1,700 & $71(11)$ \\
\hline Joypurhat & 1,200 & 600 & 1,800 & $75(12)$ \\
\hline Naogaon & 1,100 & 500 & 1,600 & $67(10)$ \\
\hline Natore & 1,200 & 900 & 2,100 & $88(13)$ \\
\hline Pabna & 1,200 & 600 & 1,800 & $75(12)$ \\
\hline Rajshahi & 1,300 & 700 & 2,000 & $88(13)$ \\
\hline Sirajganj & 1,200 & 800 & 2,000 & $83(13)$ \\
\hline Average & 1,200 & 671 & 1,896 & $79(12)$ \\
\hline
\end{tabular}

Source: Field survey 2017, Note: Figures in the bracket is the paddy equivalent labour cost of weeding as percent of total paddy production in per bigha land. One bigha equals 33 decimal. 
production in per bigha land in the survey villages of Rajshahi division. Normally, two times hand weeding was required to control weed in rice cultivation. However, in some places, additional hand weeding was needed due to severity of weed infestation.

The key informants said that most of the farmers applied one dose of weedicide in the rice fields within 5-7 days after transplanting in the case study villages in the Rangpur division (Table 8). Farmers mentioned that application of herbicides was not only highly cost effective but also not at all harmful for rice crops. Besides, most of the survey villages in Rangpur division, family and hired labourers manually uprooted the weeds from the rice fields once within 25-30 days after transplanting. Per bigha cost of labour for weeding varied largely ie ranged Tk 100-1,500 between the districts in the region because of variation in labour wage (Tk 200-400 per man-day) and severity of weed infestation. On the other hand, per bigha weeding cost in Rajshahi division (Tk 1,5002,100 ) was largely higher than that for Rangpur division (Tk 1,000-1,500). It was because farmers in the survey villages in Rajshahi division mainly relied on labour for weed control (2-3 manual weeding) while farmers in the Rangpur division employed labour (1-2 manual weeding) as well as applied weedicide (Table 7 and 8). Per bigha cost of weedicide was Tk 100-150, which was highly cost effective than manual weeding as application of weedicide saved labour cost for at least one manual weeding (Tk 800-1,200) and reduced labour requirements for following manual weeding because of less weed infestation. The paddy equivalant labour cost of weeding per bigha land was ranged between $42-63 \mathrm{~kg}$, which was about 6-9\% of total paddy production in per bigha land in the survey villages of Rangpur division.

\section{Harvesting}

Labour cost of harvesting included harvesting paddy by sickle, binding and carrying to the farmers' homeyard by head and shoulder. Farmers paid cash as labour wage for manual harvesting of rice in most of the survey villages under Rajshahi division except in Naogaon district where about $15 \%$ of total harvested paddy was paid to labour as wage (Table 9). Per bigha cost of labour for harvesting rice was largely varied (Tk 1,500-2,100) obviously due to variation in the wages between the districts and the distance between crop field to the farmers' home as carrying cost was included in harvesting. The paddy eqivalant labour cost of harvesting per bigha land was $67-98 \mathrm{~kg}$, which was about $10-15 \%$ of total paddy production in the survey villages of Rajshahi division.

Cropping intensity was high in Rangpur division and labour cost was relatively lower than those of other divisions. Labour scarcity existed in Gaibandha and Kurigram districts

Table 8. Labour cost in manual weeding of Boro rice in Rangpur division.

\begin{tabular}{lccccc}
\hline District & $\begin{array}{c}\text { Number of } \\
\text { weeding }\end{array}$ & $\begin{array}{c}\text { Labour } \\
\text { man-days bigh } a^{-1}\end{array}$ & $\begin{array}{c}\text { Wages } \\
\text { Tk man-day }\end{array}$ & $\begin{array}{c}\text { Labour cost } \\
\text { Tk bigh } a^{-1}\end{array}$ & $\begin{array}{c}\text { Paddy equivalent } \\
\text { labour cost kg bigha }\end{array}$ \\
\hline Dinajpur & 1 & 4 & 300 & 1,200 & $50(8)$ \\
Gaibandha & 1 & 4 & 250 & 1,000 & $42(6)$ \\
Kurigram & 2 & 6 & 250 & 1,500 & $63(10)$ \\
Lalmonirhat & 1 & 5 & 200 & 1,000 & $42(6)$ \\
Panchgarh & 1 & 3 & 400 & 1,200 & $50(8)$ \\
Rangpur & 2 & 7 & 200 & 1,400 & $67(10)$ \\
Thakurgaon & 1 & 4 & 300 & 1,200 & $58(9)$ \\
Average & 1 & 5 & 271 & 1,214 & $51(8)$ \\
\hline
\end{tabular}

Source: Field survey 2017, Note: Figures in the bracket is the paddy equivalent labour cost of weeding as percent of total paddy production in per bigha land. One bigha equals 33 decimal. 
Table 9. Labour cost of manual harvesting of rice in Rajshahi division.

\begin{tabular}{lcc}
\hline District & Labour cost Tk bigha $a^{-1}$ & ${\text { Paddy equivalent cost, } \mathrm{kg} b i g h a^{-1}}^{\text {Bogra }}$ \\
Chapainawabganj & 2,100 & $88(13)$ \\
Joypurhat & 1,500 & $63(10)$ \\
Naogaon & 2,000 & $83(13)$ \\
Natore & $6 \mathrm{~kg}$ paddy per $40 \mathrm{~kg}$ & $98(15)$ \\
Pabna & 1,800 & $75(12)$ \\
Rajshahi & 2,000 & $83(13)$ \\
Sirajganj & 1,600 & $67(10)$ \\
Average & 2,100 & $88(13)$ \\
\hline
\end{tabular}

Source: Field survey 2017, Note: Figures in the bracket is the paddy equivalant labour cost of harvesting rice as percent of total paddy production in per bigha land. One bigha equals 33 decimal.

due to migration of labour to the capital. Harvesting cost was observed Tk 2,000 per bigha (83 $\mathrm{kg}$ paddy) in Kurigram whereas Tk 2,400 (100 kg paddy) in Rangpur district (Table 10). Harvesting cost was varied with season and weather condition. Labour crisis was observed as acute in harvesting boro rice and wage rate increased to Tk 100-200 per manday from the normal rate due to peak demand. It was estimated that paddy equivalent charge in manual harvesting was 13\% (82 kg) of total paddy production in per bigha land in the survey areas of Rajshahi division.

Table 10. Labour cost in manual harvesting of rice in Rangpur division.

\begin{tabular}{|c|c|c|}
\hline District & $\begin{array}{l}\text { Labour charge Tk } \\
\text { bigh }^{-1}\end{array}$ & $\begin{array}{l}\text { Paddy equivalent } \\
\text { cost } \mathrm{kg} b i g h a^{-1}\end{array}$ \\
\hline Dinajpur & 2,100 & $88(13)$ \\
\hline Gaibandha & 1,900 & 79 (12) \\
\hline Kurigram & 2,000 & $83(13)$ \\
\hline Lalmonirhat & 2,000 & $83(13)$ \\
\hline Panchgarh & 1,500 & $63(10)$ \\
\hline Rangpur & 2,400 & 100 (15) \\
\hline Thakurgaon & 1,800 & 75 (12) \\
\hline Average & 1,957 & $82(13)$ \\
\hline
\end{tabular}

Source: Field survey 2017, Note: Figures in the bracket is the paddy equivalant labour cost of harvesting rice as percent of total paddy production in a per bigha land. One bigha equals 33 decimal.

\section{Reaper}

Farmers stated that service providers accepted both the cash and kind (a certain amount of paddy for harvesting per unit area) as rental charge for harvesting rice. Power reaper was used in Bogra and Naogaon districts in the north-west part of Bangladesh. The rental changes of reaper in harvesting rice ranged between Tk 500-550 per bigha, which were three to four times lower than that for manual harvesting of rice (Tables 9 and 10). It was noted that carrying cost was not included in the rental charge of harvesting by reaper. Farmers expressed the potential of harvesting equipment in harvesting rice.

\section{Thresher}

In the group discussion meeting, farmers mentioned that power operated open drum thresher was widely used for threshing crops in most of the survey villages in the Rajshahi division except Sirajganj district (Table 11). The key informants mentioned that the service providers of threshers accepted both the cash and kind (a certain amount of paddy for threshing $40 \mathrm{~kg}$ rice or per unit area) payments for threshing crops. Similarly, they reported that farmers relied on service providers for threshing rice in the southern coastal and north western areas in Bangladesh (Kabir et al. 2007a; Kabir et al. 2007b). On an average, the rental charge of threshers varied from $2.5-3 \mathrm{~kg}$ for threshing $40 \mathrm{~kg}$ paddy or Tk 600 for threshing 
Table 11. Rental charge of thresher in Rajshahi division.

\begin{tabular}{lccl}
\hline District & Rental charge paddy kg $40 \mathrm{~kg}^{-1}$ & Rental charge Tk bigha ${ }^{-1}$ & \\
\hline Bogra & - & 600 & Thresher types \\
Chapainawabganj & $3(8)$ & - & ODT \\
Joypurhat & $2.5(6)$ & - & ODT \\
Naogaon & - & 600 & ODT \\
Natore & $2.5(6)$ & - & $20 \%$ ODT, 80\% Pedal thresher \\
Pabna & $3(8)$ & - & ODT \\
Rajshahi & $3(8)$ & - & ODT \\
Sirajganj & $3(8)$ & - & $20 \%$ ODT, $80 \%$ Pedal thresher
\end{tabular}

Average

$2.8(7)$

Source: Field survey 2017, Note: Figures in the bracket is the paddy equivalant charge of threshing as percent of total paddy production in per bigha land. One bigha equals 33 decimal. ODT = Open drum thresher.

rice grown in per bigha land. It can be noted that cost of fuel and wages of operator was included with the rental charge. Farmers spent 6-8\% paddy as rental charge of thresher machine in the surveyed villages of Rajshahi division.

Both the open and close drum threshers were widely used for threshing rice and other crops in Rangpur division (Table 12). Open drum thresher was more preferable than close drum thresher in this region to keep straw long after threshing. Pedal thresher was rarely used in the survey area. Key informants mentioned that a few small and marginal farmers thresh rice by hand beating to save cost in Rangpur district. Farmers replied that a large number of service providers came along with their close drum thresher in Thakurgaon and Panchgarh district from Bogra district to thresh rice and wheat. A group of wage workers and service providers of thresher jointly harvest by sickle and thresh wheat by close drum thresher on a contractual basis in those districts. The rental charge of threshing rice varied from Tk 500-700 among the districts based on the type of threshers. It was estimated that paddy equivalent charge of threshing rice was 3-4\% (21-29 $\mathrm{kg})$ paddy in the survey areas of Rangpur division. However, rental charge of thresher machine for whole day operation was Tk 200-250 for pedal and close drum thresher. The farmers paid the cost of fuel and labourers for threshing rice.

On average, farmers paid $37-47 \%$ paddy as the service/labour charge of tillage, transplanting, weeding, harvesting and threshing. Labour crisis was observed in transplanting, weeding, harvesting and threshing operation. Labour charge varied widely in transplanting, weeding and harvesting operation. Wide variation of labour charge was observed in harvesting operation due to peak demand and unavailability of labour. Harvesting cost also depended on the distance between crop field to homeyard as carrying cost was included in the harvesting activity. The mechanical intervention in harvesting operation ensured the timeliness and faster operation and reduced the cost of harvesting crops. However, the payback period of transplanter was very high due to seasonal use (Islam et al., 2016 and Islam, 2017). On the other hand, the payback period of reaper was low compared to transplanter and combine harvester (Alam et al., 2014). From the techno-economic point of view, harvesting by reaper may be one solution to reduce the cost of rice production. An entrepreneurship has been developed in the survey villages based on the rental system of farm machinery as tillage and threshing are 
Table 12. Rental charge of thresher in Rangpur division.

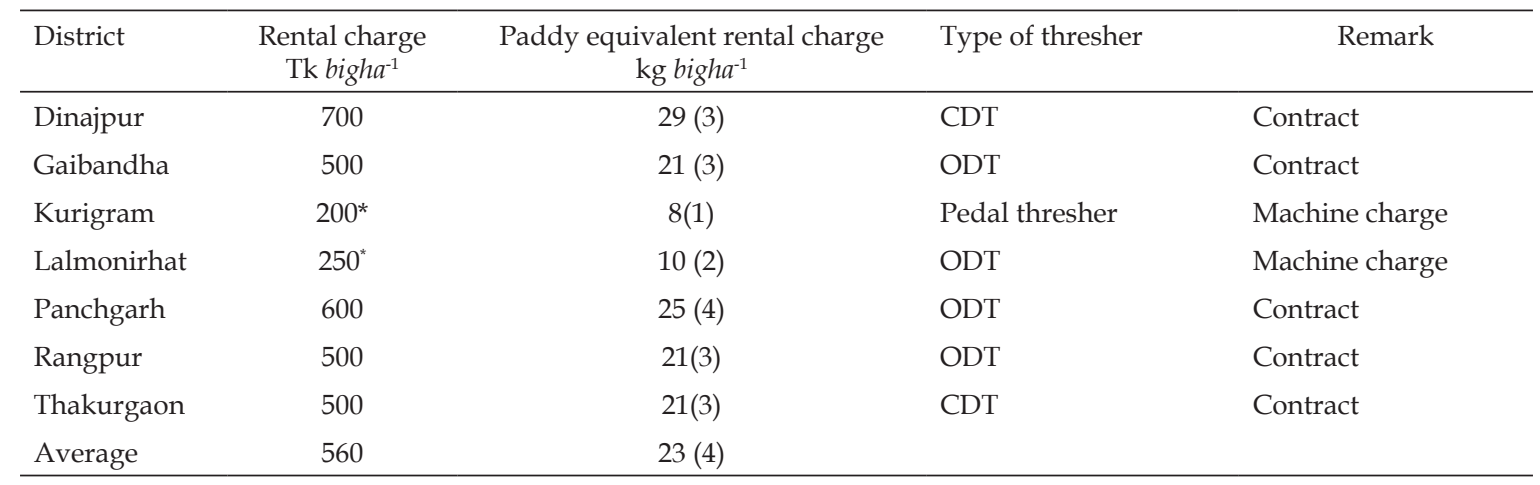

Source: Field survey 2017, Note: Figures in the bracket is the paddy equivalent charge of threshing as percent of total paddy production in per bigha land. One bigha equals 33 decimal. *Only machine rental charge (excluding labour cost) for whole day operation. $\mathrm{CDT}=$ Close drum thresher, $\mathrm{ODT}=$ Open drum thresher.

fully mechanized. The entrepreneurs earned money by renting out the close drum thresher for threshing rice and non-rice crops. Labour group purchased thresher and operate it on rental basis. Entrepreneur can invest money in harvester and thresher and operated in combined way to reduce hassle. Large scale financial assistance on the purchase of high value machines like transplanter and harvester may enahnce the mechanized cultivation, increase production and reduce cost.

\section{CONCLUSION}

Entrepreneurship of farm machinery in particular power tiller, tractor and thresher were developed and provided service to the farmers across the north-west region of the country. Most of the farmers relied on power tiller and tractor in tillage operation and power thresher in threshing crops. However, there is obvious scarcity of farm machinery in transplanting, weeding and harvesting across the regions. Therefore, farmers relied on family and hired labour in those operations. The rental charge of tillage varied between $6-7 \%$ of total paddy production across the locations because of the soil types, number of passes, and tillage types (dry or puddling). The cost of manual transplanting ranged from $7-9 \%$ of total paddy production and the weeding cost from $8-12 \%$ of total paddy depending on the severity of weed infestation, weeding regime, and application of weedicide. The paddy equivalent wage of harvesting and carrying rice ranged between $12-13 \%$ of total paddy production. Finally, the rental charge of thresher ranged between $4-7 \%$ of total paddy the farmers produced. The findings indicated that paddy equivalent cost manual of harvesting and carrying was higher followed by manual weeding and transplanting. The cost of weeding might be reduced through increasing use of weedicide. Similarly, the adoption of power reaper or combined harvester may reduce cost of harvesting rice substantially. Thus, the development of entrepreneurship on rice transplanter and harvester has wider scope for self-employment activities.

\section{REFERENCES}

Ahmed, S. 2014. Country paper presentation, Bangladesh. The 10th session of the technical committee of CSAM and regional workshop on establishing a regional database of agricultural mechanization in Asia and the Pacific, 17-19 November 2014, Siem Reap, Cambodia.

Alam, M A, M A Hossen, A K M S Islam, S Paul and M A Rahman. 2014. Performance evaluation of different types of reaper. Proceedings of BRRI annual research review workshop 2013-14. Bangladesh Rice Research Institute, Gazipur 1701. 
BBS. 2011. Statistical Yearbook of Bangladesh. Statistics and Informatics Division, Ministry of Planning, Government of the People's Republic of Bangladesh, Dhaka.

Bishay, F K. 2003. Towards sustainable agricultural development in Iraq, FAO, Rome.

BRRI (Bangladesh Rice Research Institute). 2014. .Annual Report 2013-14. Gazipur 1701, Bangladesh.

DOF. 2017. Department of Food, Ministry of Food, People's Republic of Bangladesh, Dhaka. http://dgfood. portal.gov.bd/site/page/c2dd7db7-f295-4eb18467-8b8c6de02033 accessed date.

FAO. 2006. Business management skills of agricultural farm related entrepreneurs. A case study.

Islam, A K M S. 2006. Performance evaluation of thresher. Report submitted to the FMPHT division, Bangladesh Rice Research Institute, Gazipur 1701, Bangladesh.

Islam, A K M S. 2016. Mechanized rice transplanting in Bangladesh. Publication number 218. Bangladesh Rice Research Institute, Gazipur.

Islam, A K M S, M A Rahman, A K M L Rahman, M T Islam and M I Rahman. 2016a. Techno-economic performance of 4-row self-propelled mechanical rice transplanter at farmers' field in Bangladesh. Progressive Agriculture, 27 (3): 369-382.

Islam, A K M S, M T Islam, M S Rahman, M A Rahman and $\mathrm{Y}$ Kim. 2016b. Investigation on selective mechanization for wet season rice cultivation in Bangladesh. J. of Biosystems Eng., 41 (4): 294-303.

Islam, A K M S, M T Islam, M Sh Islam, AK M L Rahman and M A Rahman. 2017. Performance evaluation of BRRI power weeder for low land rice (Oryza sativa L.) cultivation. The Agriculturists, 15 (1): 40-48.

Islam, A K M S. 2017. Mechanized rice cultivation. An unpublished book. Farm Machinery and Postharvest Technology Division, Bangladesh Rice Research Institute, Gazipur-1701, Bangladesh.
Justice, S and S Biggs. 2010. Rural and agricultural mechanization in Bangladesh and Nepal: Status, processes and outcomes, In: FAO. 2012. Farm mechanization for development, FAO (Unpublished).

Kabir, M H. 2014. Present status of custom hiring of agricultural machinery in Bangladesh. A presentation retrieved from www.un-csam.org/ ppta/ 201409RF/BD02.pdf on 28 May, 2016.

Kabir, M S, D N R Paul, M I Hossain and N M F Rahman. 2016a. Estimating area and production of rice under different crop-cut methods in Bangladesh. Bangladesh Rice J. 20 (1): 11-16.

Kabir, MS, M U Salam, A Chowdhury, N M F Rahman, K M Iftekharuddaula, M S Rahman, H Rashid, S S Dipti, A Islam, M A Latif, A K MS Islam, M M Hossain and J K Biswas. 2016b. Rice vision for Bangladesh: 2050 and beyond. Bangladesh Rice J. 19 (2): 1-18.

Kabir, M J, R Cramb, M Alauddin, C Roth and S Crimp. 2017a. Farmers' perceptions of and responses to environmental change in southwest coastal Bangladesh. Asia Pacific Viewpoint.

Kabir, M J, M Alauddin and S Crimp. 2017b. Farm-level adaptation to climate change in Western Bangladesh: An analysis of adaptation dynamics, profitability and risks. Land Use Policy, 64, pp.212-224.

MOA. 2016. Agricultural mechanization road map 2021, 2031, 2041. Ministry of Agriculture, People's Republic of Bangladesh, Dhaka.

Sattar, A S A. 1999. A brief note on bridging the yield gap in Bangladesh. An unpublished rice-rice wet seedbed system. J. Agron. 3 (4): 263-267.

Sims, R, A Röttger and S Mkomwa. 2011. Hire service by farmers for farmers. Rural Infrastructure and Agro-Industries Division, Food and Agriculture Organization of the United Nations, Rome.

Wohab, M A. 2012. Status of agricultural mechanization in Bangladesh. International Fertilizer Development Center (IFDC) Asia Division, Bangladesh. 
